\title{
Pelatihan dan Pendampingan Mata Pelajaran Bahasa Inggris bagi Siswa-Siswi Sekolah Dasar Negeri Leyangan Terdampak Pandemi COVID-19
}

\section{Training and Mentoring of English Subjects for Students at Elementary School of Leyangan Affected by the COVID-19 Pandemic}

\author{
Khusman Anhsori ${ }^{1^{*}}$, Titis Handayani ${ }^{2}$ \\ ${ }^{1,2}$ S-1 Sistem Informasi Universitas Semarang, Semarang, Indonesia \\ *Penulis Korespondensi \\ 1khuzneitherone@,gmail.com, ${ }^{2}$ titis@usm.ac.id
}

Riwayat Artikel: Dikirim 21 Juni 2021; Diterima 3 Agustus 2021; Diterbitkan 30 November 2021

\begin{abstract}
Abstrak
Sejak sistem pembelajaran jarak jauh atau study from home diberlakukan, beberapa kendala dialami oleh para siswa khususnya para siswa SD Negeri Leyangan di lingkungan RT 004 RW 002 Dusun Krajan Desa Leyangan Kecamatan Ungaran, Kabupaten Semarang. Para siswa merasa kesulitan dalam mempelajari materi yang diberikan, khususnya mata pelajaran Bahasa Inggris yang dirasa masih menjadi momok bagi para siswa. Kurangnya penjelasan materi secara langsung oleh guru serta kurangnya perhatian dan pengawasan langsung dari orang tua menjadi kendala utama dalam sistem pembelajaran online. Berdasarkan paparan tersebut, siswa membutuhkan pelatihan dan pendampingan tatap muka khususnya materi 'Pengenalan Diri' pada mata pelajaran Bahasa Inggris. Melalui program kerja KKN BV USM, pengabdi memfokuskan pengabdian masyarakat pada pelatihan dan pendampingan secara tatap muka untuk meningkatkan kemampuan berbahasa Inggris para siswa. Metode yang digunakan dalam pengabdian masyarakat ini metode penjelasan materi secara langsung dan praktikum speaking pada beberapa contoh kalimat yang diberikan. Para peserta diwajibkan menyimak, menuliskan ulang dan membaca setiap materi yang dipaparkan. Program pelatihan dilaksanakan pada bulan Juni 2021 secara tatap muka dengan menerapkan protokol kesehatan COVID-19. Hasil evaluasi para praktik speaking pada pelatihan ini yaitu peningkatan pengetahuan dan keterampilan para siswa pada materi 'Pengenalan Diri' dan pronunciation yang lebih baik.
\end{abstract}

Kata Kunci: Pembelajaran jarak jauh, Sekolah dasar, Pengenalan diri, COVID-19

\begin{abstract}
Since the study from home system was implemented, several obstacles were found, especially for students at Elementary School of Leyangan in RT 004 RW 002 Dusun Krajan Desa Leyangan Kecamatan Ungaran Timur, Kabupaten Semarang. The students were difficult to learn the subjects by themselves, expecially for English subject. The main obstacles of study from home were lack of teacher's direct explanation and lack of parents' attention and mentoring. Based on this explanation, students needed face-to-face training and monitoring, especially the 'Self-Introduction' in English subjects. Through the USM's Students Community Services Back to Village program, student focused on community service for face-to-face training and mentoring to improve the English skills for students at Elementary School of Leyangan. The community services method used was directly explanation and speaking practice for the given example sentences. The participants were required ro listen, rewrite and practice to speak for the given subjects. The mentoring was held in June 2021 with the COVID-19 health protocol face-to-face method. Evaluation results of the speaking pratice showed increment in students' knowledge and skill of 'Self-Introduction' subject and better pronunciation.
\end{abstract}

Keywords: Study from home, Elementary school, Self introduction, COVID-19

\section{PENDAHULUAN}

Awal tahun 2020, wabah pneumonia baru yang berawal dari Wuhan, Provinsi
Hubei, China menyebar dengan sangat pesat ke seluruh dunia. Kemudian wabah tersebut diberi nama Coronavirus Disease 
2019 (COVID-19).

COVID-19

disebabkan oleh Acurate Respiratory Syndrome Coronavirus-2 (SARS-CoV-2) (Susilo et al., 2020). Penyakit ini merupakan penyakit baru yang berubah menjadi pandemi yang tentu saja harus diwaspadai karena hingga saat ini penyebaran penyakit ini relatif cepat, dan hingga saat ini belum ditemukan obatnya oleh para ahli dan peneliti.

Pandemi

COVID-19

mempengaruhi di segala bidang aspek kehidupan manusia, baik itu dari segi sosial, ekonomi, hingga pendidikan. Salah satu dampak COVID-19 yang dirasakan pada aspek pendidikan adalah diberlakukannya sistem pendidikan dan sistem pembelajaran secara daring (online). Sistem pembelajaran ini berlaku pada semua jenjang akademik mulai dari TK, SD, SMP, SMA dan Perguruan Tinggi. Pendidikan pada masa pandemi seperti ini, sudah sewajarnya bagi mahasiswa untuk turut berkontribusi memberikan gagasan dalam penyelesaian masalah di lingkungan bermasyarakat khususnya pada bidang pendidikan. Sebagai salah satu upaya problem solving yang dapat dilakukan mahasiswa adalah program pengabdian masyarakat yang diterapkan dalam kegiatan Kuliah Kerja Nyata (KKN).

Program KKN merupakan program rutin tahunan yang wajib dilaksanakan setiap mahasiswa di Indonesia sebagai bentuk implementasi Tri Dharma Perguruan Tinggi dengan menitikberatkan pada kegiatan akademik yang bersifat kurikuler dan melibatkan masyarakat secara langsung (Hakim, 2021). Universitas Semarang (USM) adalah salah satu perguruan tinggi swasta di Semarang yang tetap mewajibkan seluruh mahasiswa jenjang Strata-1 (S-1) untuk tetap memberikan kontribusi baik tenaga maupun ide gagasan dalam kegiatan KKN. Dalam masa pandemi seperti ini, tema KKN yang diambil oleh USM adalah
Kuliah Kerja Nyata Back to Village (KKN BV) dimana pada semester genap tahun ajaran 2020/2021 memasuki periode ke-3.

Sesuai dengan tema yang ditetapkan, seluruh mahasiswa USM peserta KKN BV wajib melaksanakan program kerja KKN BV di lingkungan rumah masing-masing dengan tetap menerapkan protokol kesehatan sesuai anjuran pemerintah. Sesuai sistem yang ditetapkan oleh pemerintah pada masa pandemi ini bahwa seluruh kegiatan belajar mengajar dilaksanakan secara daring dengan memanfaatkan teknologi informasi, yang kemudian dikenal dengan sistem pembelajaran jarak jauh atau belajar dari rumah (study from home). Sistem pembelajaran ini menyebar merata di seluruh wilayah Indonesia, baik itu di lingkungan kota besar hingga pedesaan. Salah satu jenjang akademik formal yang juga menerapkan study from home atau pembelajaran jarak jauh adalah SD Negeri Leyangan. SD Negeri Leyangan merupakan sekolah dasar negeri yang terletak di Dusun Krajan Desa Leyangan Kecamatan Ungaran Timur Kabupaten Semarang, dan menjadi satu-satunya sekolah dasar di Desa Leyangan.

Desa Leyangan adalah salah satu kelurahan yang terletak di Kecamatan Ungaran Timur, Kabupaten Semarang. Sesuai data kependudukan di kantor kelurahan, Desa Leyangan memiliki 4 (empat) dusun yang terdiri dari 14 (empat belas) RW. Adapun nama-nama dusun tersebut adalah Dusun Krajan, Dusun Lengkong, Dusun Jetis dan Dusun Kopeng, dimana letak pusat pemerintahannya berada di Dusun Krajan. Hampir semua anak-anak usia sekolah dasar di Dusun Krajan dan Dusun Lengkong mengenyam pendidikan di SD Negeri Leyangan.

Sistem pembelajaran daring mulai diberlakukan di SD Negeri Leyangan sejak Maret 2020 ketika wabah pandemi 
COVID-19 mulai meningkat di Kecamatan Ungaran Timur. Berbagai kendala dialami oleh para siswa dan orang tua siswa selama proses pembelajaran daring berlangsung. Beberapa kendala yang dihadapi oleh para siswa adalah keterbatasan sinyal, kurangnya penjelasan materi secara langsung oleh guru kelas dan guru mata pelajaran khusus (guru Bahasa Inggris), kurangnya perhatian khusus dari orang tua murid, serta kurangnya waktu pengawasan dari orang tua.

Seperti yang dijelaskan sebelumnya, salah satu kendala yang dihadapi oleh para siswa adalah kurangnya penjelasan materi secara langsung oleh guru kelas dan guru Bahasa Inggris. Sesuai dengan hasil interview yang dilakukan pengabdi kepada beberapa siswa, didapatkan informasi bahwasanya guru Bahasa Inggris di SD Negeri Leyangan sudah sekitar satu tahun mengundurkan diri dari sekolah dan belum mendapatkan guru pengganti. Selain itu, guru kelas jarang memberikan penjelasan secara langsung kepada para siswa, khususnya dalam mata pelajaran Bahasa Inggris. Guru kelas hanya memberikan lembar kerja siswa (LKS) kepada para siswa. Para siswa diwajibkan untuk mengerjakan beberapa soal latihan yang ada pada LKS, yang kemudian harus dikumpulkan sesuai dengan jadwal yang sudah ditentukan oleh guru.

Kendala kedua yang dihadapi para siswa adalah kurangnya perhatian khusus dan kurangnya pengawasan dari orang tua selama proses pembelajaran jarak jauh berlangsung. Hampir $85 \%$ orang tua siswa SD Negeri Leyangan di lingkungan RT 004 RW 002 Dusun Krajan Desa Leyangan adalah pekerja industri yang diharuskan bekerja dengan sistem shifting. Sehingga para orang tua siswa tidak memiliki cukup waktu dalam pendampingan pembelajaran. Selain itu, Bahasa Inggris rupanya masih menjadi mata pelajaran yang dirasa sulit bagi para siswa dan orang tua.

Berdasarkan latar belakang masalah tersebut, pengabdi berusaha menerapkan program kerja KKN BV dengan melakukan pelatihan dan pendampingan secara tatap muka khususnya mata pelajaran Bahasa Inggris bagi para siswa SD Negeri Leyangan yang terdampak pandemi COVID-19, khususnya di lingkungan RT 004 RW 002 Dusun Krajan Desa Leyangan Kecamatan Ungaran Timur Kabupaten Semarang. Adapun materi umum yang dijelaskan kepada para siswa adalah materi pengenalan diri atau self introduction, dimana beberapa sub materi yang dijelaskan akan dijabarkan pada bab Hasil dan Pembahasan.

\section{METODE PENELITIAN}

Metode pelaksanaan penelitian pada kegiatan KKN BV menggunakan metode pendampingan, melalui tahap-tahap antara lain (Sulistyaningrum, 2020):

\section{Menentukan daerah sasaran}

Sesuai dengan tema KKN BV yang diterapkan oleh USM, pengabdi melaksanakan program kerja KKN BV di lokasi sekitar rumah pengabdi yaitu lingkungan Dusun Krajan RT 004 RW 002 Desa Leyangan Kecamatan Ungaran Timur Kabupaten Semarang.

\section{Melakukan perizinan}

Pada tanggal 28 April 2021, pengabdi melakukan permohonan izin kepada ketua RT setempat guna melaksanakan kegiatan program kerja KKN BV di Dusun Krajan RT 004 RW 002 Desa Leyangan Kecamatan Ungaran Timur Kabupaten Semarang.

\section{Pengumpulan data}

Teknik pengumpulan data dilakukan dengan cara interview kepada para siswa dan orang tua di lingkungan Dusun Krajan RT 004 RW 002 Leyangan pada tanggal 17 
sampai dengan tanggal 23 Mei 2021. Berikut rangkuman hasil interview kepada salah satu siswa dan orang tua murid.

Siswa A menanggapi pertanyaan dari pengabdi yang dipaparkan dibawah ini.

Pengabdi : "Apakah selama pandemi dan proses belajar di rumah, pernah dijelaskan materi Bahasa Inggris secara langsung oleh Guru?"

Siswa A : "Tidak pernah, karena Bu Guru mata pelajaran Bahasa Inggris sudah setahun tidak mengajar (mengundurkan diri) dan belum ada penggantinya. $\mathrm{Bu}$ Guru (guru kelas) juga tidak pernah menjelaskan materi yang ada pada LKS."

Pengabdi : "Lantas, bagaimana proses pembelajarannya selama ini?"

Siswa A : "Saya berangkat untuk mengambil LKS kemudian diberi tugas untuk mengerjakan halaman tertentu, kemudian hari berikutnya (sesuai arahan guru) LKS tersebut dikumpulkan kembali untuk dinilai."

Berdasarkan data yang terkumpul, sistem pembelajaran tersebut berlangsung dalam kurun waktu selama pembelajaran jarak jauh atau daring (online). Jadwal para siswa untuk berangkat ke sekolah diinformasikan kepada orang tua siswa melalui aplikasi chat Whats $A p p$.

Interview kedua dilakukan pengabdi kepada orang tua siswa dengan rangkuman dibawah ini.

Pengabdi : "Apakah Anda rutin membantu Siswa A belajar setiap hari Bu?"
Orang : "Jarang sekali Mas, risiko Tua sebagai buruh pabrik.

Siswa A Sistem kerjanya bergilir (shifting), jadi kalau pas masuk siang atau malam hampir tidak pernah cek PR-nya anak."

Pengabdi :"Apakah pernah mengajarkan Bahasa Inggris kepada Siswa A, Bu?"

Orang : "Boro-boro Mas, Bahasa Tua Inggris saja saya tidak Siswa A paham. Sulit Mas.”

Hasil interview di atas dapat ditarik kesimpulan terdapat tiga kendala utama dalam proses pembelajaran daring yang selama ini berlangsung di lingkungan Dusun Krajan RT 004 RW 002 Desa Leyangan seperti yang sudah dijelaskan pada latar belakang.

\section{Implemenasi kepada masyarakat}

Kegiatan pelatihan dan pendampingan mata pelajaran Bahasa Inggris dilaksanakan secara tatap muka di rumah pengabdi setiap akhir pekan pada bulan Juni 2021, kegiatan dimulai pada pukul 08.00 WIB dan berakhir pada pukul 11.00 WIB. Kegiatan dilaksanakan dengan menerapkan protokol kesehatan dimana para siswa harus menggunakan masker dan memberikan batasan maksimal jumlah siswa yang hadir pada waktu pelatihan. Adapun total seluruh peserta yang mengikuti kegiatan pelatihan berjumlah 7 (tujuh) siswa.

\section{Evaluasi}

Evaluasi kegiatan dilakukan selama dan setelah kegiatan dilaksanakan. Evaluasi didasarkan tingkat pemahaman para siswa dalam pemahaman materi Bahasa Inggris yang diajarkan. Evaluasi selama kegiatan dilakukan setiap sesi pertemuan selesai, sedangkan evaluasi setelah kegiatan

Khusman Anbsori, Titis Handayani 
dilakukan pada pertemuan akhir pelatihan dan pendampingan program kerja KKN BV.

\section{HASIL DAN PEMBAHASAN}

Pelaksanaan pengabdian masyarakat melalui pelatihan dan pendampingan mata pelajaran Bahasa Inggris diawali pada hari Minggu, 06 Juni 2021 di rumah pengabdi. Seluruh kegiatan dilaksanakan setiap akhir pekan, pada hari Sabtu dan Minggu selama bulan Juni 2021 yang dimulai pada pukul 08.00 sampai dengan pukul 11.00 WIB. Materi yang disajikan pada setiap pertemuan berbeda-beda sesuai dengan materi utama yang pengabdi paparkan yaitu Self Introduction, dimana sub-sub materi yang diajarkan kepada para siswa tersaji dalam tabel 1 berikut:

Tabel 1.

Tabel Jadwal dan Materi Pelaksanaan KKN BV

\begin{tabular}{|c|c|l|}
\hline No & Tanggal & \multicolumn{1}{|c|}{ Materi } \\
\hline 1 & 06 Juni & $\begin{array}{l}\bullet \text { Subject and Verb } \\
\bullet \text { Numbers }\end{array}$ \\
\hline 2 & 12 Juni & Greetings \\
\hline 3 & 13 Juni & Food and Drink \\
\hline 4 & 19 Juni & Things around School \\
\hline 5 & 20 Juni & Environmental \\
\hline 6 & 26 Juni & Animals \& Vehicles \\
\hline 7 & 27 Juni & Self Introduction \\
\hline
\end{tabular}

Sistem pelatihan yang diberikan pengabdi kepada para siswa adalah dengan menjelaskan setiap materi dengan memberikan beberapa contoh kalimat sesuai dengan sub materi yang tersaji. Kemudian para siswa diajarkan pronunciation atau bagaimana cara mengucapkan setiap kalimat pada contoh yang diberikan. Pengabdi menjelaskan materi dengan menuliskannya pada whiteboard, kemudian para siswa diwajibkan untuk menulis ulang materi ke dalam buku tulis atau buku catatan masing-masing, seperti yang tersaji pada Gambar 1 dan
Gambar 2 bertikut ini. Penerapan tiga bidang sistem pembelajaran yaitu menyimak materi, membaca kembali contoh kalimat yang diberikan dan mencatat materi, bertujuan agar para siswa lebih mudah dalam menghafal materi dibandingkan hanya dengan menyimak penjelasan materi.

\section{Gambar 1.}

Materi yang Ditulis Pengabdi pada Whiteboard

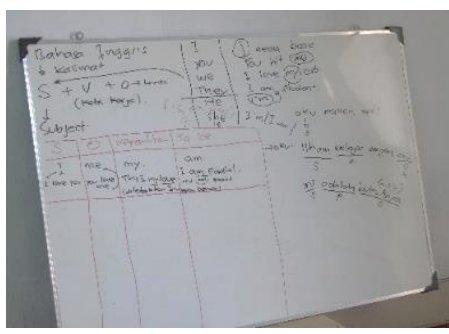

Sumber: Dokumentasi Pribadi

Gambar 2.

Materi yang Ditulis Ulang Peserta Pelatihan dan Pendampingan

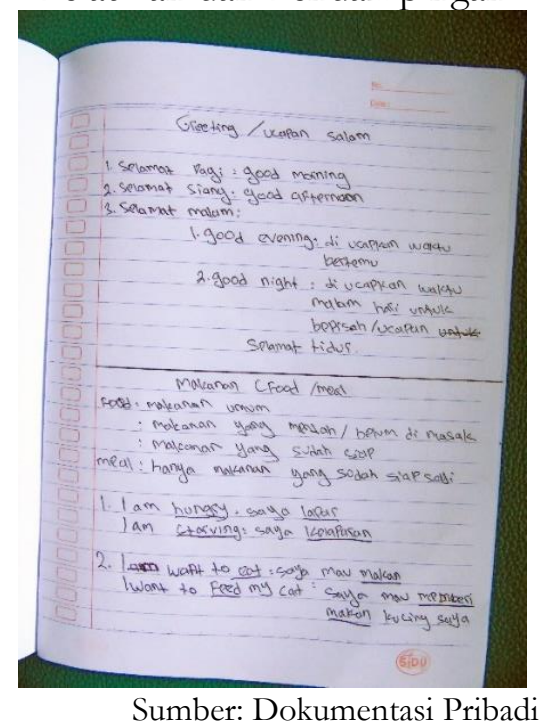

Pemberian materi awal adalah subject and verb, dimana pengabdi menjelaskan secara singkat dan jelas tentang unsur utama yang harus dimiliki dalam membentuk suatu kalimat dalam Bahasa Inggris. Berdasarkan interview awal yang diperoleh, bahwasanya para siswa belum mendapat penjelasan apa saja unsur utama yang harus dimiliki dalam membentuk 
suatu kalimat, baik itu dalam pembentukan kalimat Bahasa Indonesia maupun Bahasa Inggris. Hal tersebut menjadi kendala utama apabila usia sekolah dasar belum mendapat penjelasan terkait unsur-unsur utama dalam pembentukan kalimat.

Antusiasme ditunjukkan oleh para siswa saat pengabdi menawarkan kepada mereka terkait materi yang hendak dipelajari. Sesuai kesepakatan antara pengabdi dan para siswa, pertemuan berikutnya pada Sabtu dan Minggu 12 dan 13 Juni 2021, materi yang dipaparkan adalah Greetings dan Food and Drink. Pada kedua materi tersebut, para siswa akan dijelaskan bagaimana penggunaan salam dalam Bahasa Inggris, bagaimana cara menanyakan dan menjawab kabar, bagaimana cara mengungkapkan rasa lapar dan haus, serta beberapa jenis makanan dan minuman di lingkungan sekitar. Seperti yang terlihat pada Gambar 3, saat beberapa peserta pelatihan menulis ulang materi yang dipaparkan.

Gambar 3.

Peserta Mencatat Materi yang Dipaparkan

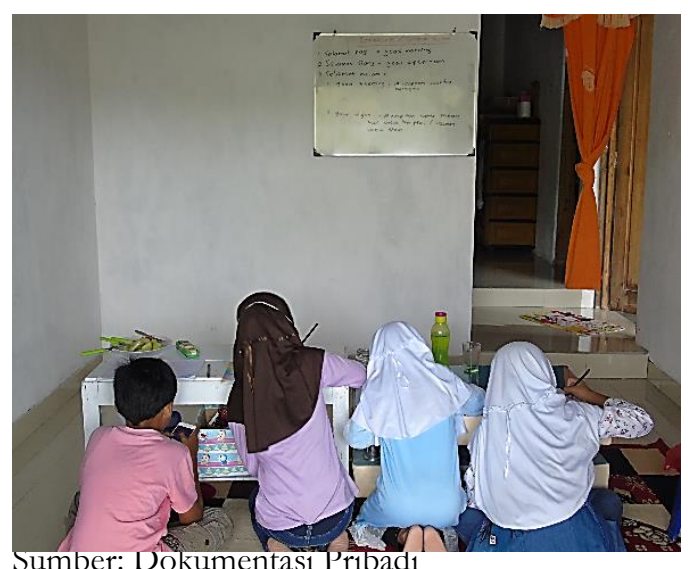

Kemudian pada pemaparan materi Things around School, materi yang disajikan merupakan jenis-jenis benda yang biasa mereka temui di lingkungan sekolah. Sedangkan materi Environmental menyajikan jenis-jenis benda yang mereka temui di lingkungan rumah, baik di dalam maupun di luar rumah. Euphoria para siswa tidak bisa ditutupi ketika materi Animals \& Vehicles dipaparkan, karena pada pemaparan materi tersebut pengabdi memberikan beberapa contoh gambar hewan melalui proyektor. Para siswa berlomba menjawab nama-nama hewan dalam Bahasa Inggris ketika beberapa kali gambar hewan tampil melalui proyektor.

Self Introduction merupakan materi terakhir yang dipaparkan kepada para siswa. Pengabdi menjelaskan secara singkat bagaimana memperkenalkan diri sendiri menggunakan Bahasa Inggris. Oleh pengabdi, para siswa diwajibkan mempraktikkan materi self introduction secara singkat. Dengan praktik speaking secara langsung, diharapkan para siswa mampu menumbuhkan rasa percaya diri dan melatih pronunciation. Hasil praktik speaking salah satu siswa dapat dilihat pada Gambar 4.

"Good morning. My name is Fadbil. I am 10 years old. My bobby is (playing) football. I love meatballs."

Gambar 4.

Peserta Pelatihan Praktik Speaking 'Self Introduction'

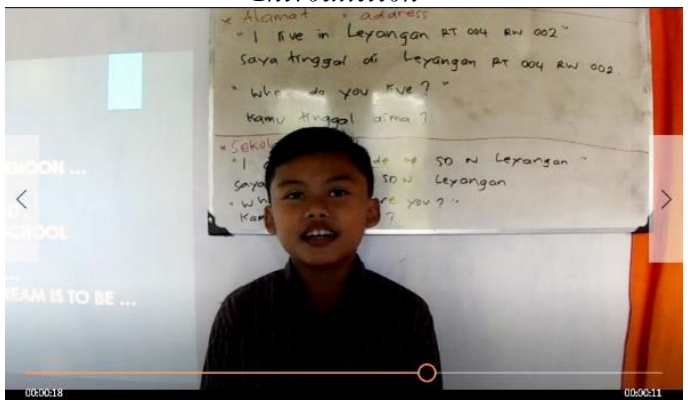

Sumber: Dokumentasi Pribadi

Pemaparan materi sesuai dengan jadwal dan sub-sub materi yang disajikan pada tabel 1 berjalan lancar hingga akhir pertemuan. Pentingnya pelatihan dan pendampingan tatap muka seperti ini mampu mengurangi kejenuhan para siswa yang disebabkan sistem pembelajaran daring. Dengan pendampingan tatap

Khusman Anhsori, Titis Handayani

DOI: https://doi.org/10.26714/jsm.4.1.2021.52-59 
muka, pengabdi dapat memonitoring secara langsung beberapa kesalahan saat para siswa mempraktikkan sesi speaking dan reading dari materi yang dipaparkan pengabdi.

Pada sesi akhir, pengabdi dan para siswa melakukan evaluasi terhadap kegiatan pelatihan yang sudah terlaksana. Evaluasi dilaksanakan dengan sistem pengabdi melakukan sedikit interview terkait materi yang telah dipaparkan. Berikut rangkuman hasil interview kepada dua siswa peserta pelatihan dan pendampingan.
Pengabdi : "Bagaimana materi yang sudah dijelaskan?"

Siswa A : "Albamdulilah materinya mudah dipahami. Saya belajar banyak bagaimana cara mengucapkan beberapa kata dan kalimat dalam Bahasa Inggris. Kalau hanya lewat LKS saya tidak paham."

Menurut rangkuman interview di atas, dapat ditarik kesimpulan bahwasanya pelatihan dan pendampingan tatap muka memang diperlukan bagi para siswa. Mereka lebih mudah mempelajari kosakata dan kalimat, dan tidak segan untuk bertanya secara langsung kepada pengabdi apabila ada beberapa kosakata yang dirasa masih sulit pengucapannya.

Selanjutnya Siswa B menanggapi pertanyaan dari pengabdi yang dapat dilihat di bawah ini.

Pengabdi : "Apakah menurut kamu belajar tatap muka seperti ini menarik?"

Siswa B : "Iya Mas. Saya bingung karena tidak pernah mendapat penjelasan langsung dari $\mathrm{Bu}$ Guru. Bosan belajar sendiri di rumah Mas, kalau begini kan belajar banyak temannya, jadi gak bosan."

Berdasarkan rangkuman interview di atas, pelatihan dan pendampingan tatap muka seperti ini mampu menghilangkan kejenuhan para siswa selama masa pandemi COVID-19 yang memberlakukan pembelajaran jarak jauh. Kendala utama yang ditemui para siswa adalah kurangnya pendampingan secara langsung dari guru dan orang tua. Hal tersebut mengakibatkan minat belajar para siswa menurun secara drastis, sehingga beberapa materi tidak dapat dipahami dengan maksimal.

Kegiatan pelatihan dan pendampingan ini membuahkan hasil dengan meningkatnya pengetahuan dan keterampilan para siswa, khususnya untuk materi "Self Introduction". Berdasarkan hasil dari beberapa kali praktikum speaking yang dilakukan oleh para siswa dengan didampingi oleh pengabdi, keterampilan pronunciation para siswa meningkat secara signifikan dari pertemuan pertama. Pemahaman para siswa dalam penggunaan dan penyusunan kalimat keseharian (daily activity) menggunakan Bahasa Inggris juga jauh lebih baik.

Hambatan yang dihadapi pengabdi dalam pelaksanaan pengabdian ini antara lain waktu belajar yang terbatas. Guna mencegah penularan COVID-19, maka pendampingan hanya dilaksanakan selama 3 (tiga) jam pada akhir pekan. Selain itu juga diberlakukan pembatasan total siswa yang hadir dalam pendampingan tersebut, maksimal 10 siswa. Kendala lain yang dihadapi adalah bahwa beberapa siswa kurang begitu tertarik dengan adanya pelatihan dan pendampingan tersebut meskipun pengabdi sudah merangkul para siswa dan orang tua dengan alasan lebih memilih bermain daripada belajar bersama.

Solusi yang pengabdi dapat berikan yaitu diperlukan penguasaan metode-

Khusman Anbsori, Titis Handayani

DOI: https://doi.org/10.26714/jsm.4.1.2021.52-59 
metode efektif pembelajaran tatap muka dengan mempertimbangkan pembatasan jumlah siswa, dikarenakan pengabdi hanya mampu memberikan pelatihan dan pendampingan melalui program kerja pelaksanaan KKN BV. Diharapkan guru dan tenaga pengajar dapat memberikan metode pengajaran yang sesuai selama pembelajaran di masa pandemi COVID19 guna mengurangi kejenuhan selama masa pembelajaran jarak jauh atau study from home.

\section{KESIMPULAN}

Kesimpulan yang dapat diambil dari pelaksanaan pengabdian masyarakat ini antara lain:

1. Pengabdian masyarakat melalui pelatihan dan pendampingan mata pelajaran Bahasa Inggris bagi para siswa SD Negeri Leyangan di lingkungan Dusun Krajan RT 004 RW 002 dapat diterima dengan baik oleh para siswa dan orang tua. Kegiatan ini mampu mencapai tujuan yang sudah direncanakan yaitu membantu para siswa dalam pemahaman materi dan kalimat sehari-hari.

2. Para siswa peserta pelatihan dan pendampingan merasa puas dengan program kerja yang dipaparkan pengabdi dalam kegiatan $\mathrm{KKN}$ BV USM.

3. Metode pembelajaran tatap muka perlu dilaksanakan di sekolah guna menghilangkan kejenuhan para siswa selama pembelajaran jarak jauh dengan tetap menerapkan protokol kesehatan sesuai anjuran pemerintah.

\section{DAFTAR PUSTAKA}

Susilo, A. Rumende, M. C., et al. (2020). Coronavirus Disease 2019: Tinjuaun Literatur Terkini. Jurna Penyakit Dalam. Vol. 7. No. 1. Hal. 45-67. http://jurnalpenyakitdalam.ui.ac.id Lindex.php/ipdi/article/view/415

Al Hakim, R. R. (2020). Pencegahan Penularan COVID-19 Berbasis Aplikasi Android Sebagai Implementasi Kegiatan KKN Tematik COVID-19 di Sokanegara Purwokerto Banyumas. Community Engagement and Emergence Journal (CEEJ). Vol. 2. No. 1. Hal. 7-13. https://journal.yrpipku.com/index. $\mathrm{php} / \mathrm{ceej} /$ article/view/125

Sulistyaningrum, D. Al Hakim, R. R. (2020). Pendampingan

Pembelajaran Siswa Melalui Teknologi Informasi Selama Pandemi COVID-19: Studi Kasus KKN Tematik COVID-19. AND ASIH Jurnal Pengabdian kepada Masyarakat. Vol. 1. No. 2. Hal. 1-7. http://jurnal.umitra.ac.id/index.ph $\mathrm{p} / \mathrm{ANDASIH} /$ article/view/396

Wijayatiningsih, D. T., et al. (2020). Storytelling: Peningkatan High Order Thinking Skills Siswa Sekolah Dasar Negeri 03 Ujung-Ujung Pabelan Semarang. Jurnal Surya Masyarakat. Vol. 3. No. 1. Hal. 7-14. https://jurnal.unimus.ac.id/index.p $\mathrm{hp} / \mathrm{JSM} /$ article/view/6200

Khusman Anhsori, Titis Handayani 